This article is available open access under a CC BY 4.0 license as part of Berghahn Open Anthro, a subscribe-to-open model for APC-free open access made possible by the journal's subscribers.

\title{
Digital FAILURES IN ABOLITIONIST ETHNOGRAPHY
}

\author{
Jason Bartholomew Scott
}

\begin{abstract}
In an era when grassroots activism is defined by the use of social media, the democratic potentials of the Internet are constantly confronted by a shifting set of practical and political obstacles. Organizations seeking to abolish violent policing, for example, use social media to mobilize widespread support, but can fail to solidify lasting influence within government institutions. Similarly, twenty-first-century ethnographers have gained the ability to interact with grassroots organizations over social media, but often fail to gain insight into a movement's internal politics or day-to-day struggles. This article focuses on the challenges of anti-violence activists in Brazilian favelas following the 2016 Rio de Janeiro Olympics. The author explores how ethnographers can create a sense of continuity out of digital failure.
\end{abstract}

Keywords: abolition, Brazil, digital ethnography, digital rupture, failure, favelas, social media activists

Following the 2016 impeachment of Brazilian President Dilma Rousseff and the 2016 Rio de Janeiro Olympics, favela-based activists struggled to defend their communities. For years, anti-police activists had risen to fame as social media personalities, reporting on the violent reality of the favela and garnering a broad network of support from a global civil society. However, shoot-outs between police and drug traffickers became more frequent, and violent threats of censorship caused activists to express a sense of failure. Even the inclusive and democratic promises of the information society seemed unable to provide the infrastructure for lasting criminal justice reform that many in the favela sought.

As I observed activists express a sense of frustration about the diminishing reach of their social media campaigns, I began to believe that digital platforms 
had also failed to create a reliable form of ethnographic communication between myself and my interlocutors. A frustrated sense of failure, sometimes expressed as a momentary loss of purpose and intent, became an essential condition for how I understood both twenty-first-century activist movements and the potentials for digital ethnography. Social media can amplify a plurality of voices, but it can also create digital blind spots that obscure the visibility of an activist movement's central narratives, expressions of fatigue, and reactions to failure. By aligning my own sense of analytical shortcomings with the types of failure experienced by twenty-first-century police abolitionists in Rio's favelas, I see the potential for a type of digital ethnography that conceptualizes failure not just as a disruptive obstacle inherent in social media analysis, but as a generative space where new interpretive and analytical possibilities can be imagined.

\section{Eduardo and Agatha}

In 2015, I read on Facebook that a 10-year-old boy named Eduardo had been shot in the head. Eduardo lived in one of Brazil's most notorious favela communities named the Complexo do Alemão. Daily shoot-outs between police and drug traffickers had killed dozens of innocent bystanders in the previous months. His school shuttered, Eduardo had been playing games on a smartphone in front of his home when a passing police patrol turned a nearby corner and, within a second, fired a half-dozen shots. The immediate aftermath of Eduardo's death was captured on video by a neighbor and shared thousands of times on social media. In the video, dozens of neighbors screamed "Covardes!" (Cowards!) at the police as they walked away, leaving Eduardo's bloody body folded over itself on the ground.

I had lived near Eduardo's home for almost a year at the time of his murder. While the initial videos terrified me, my emotional and physical memory of Eduardo's murder outweighed the detailed knowledge I found online. I attended a reconstruction of Eduardo's murder and could not help but notice how every aspect of the scene appeared an arm's length away. The narrow stairway that steeply climbed up his beco (alleyway) was barely a meter wide. Eduardo was shot by a meter-long rifle from less than five meters away. Eduardo stood a little over a meter from the ground. This intimacy engendered a sense of emotional arrival, grounding both the fears of random violence that I experienced walking in the Complexo each day and a sense of empathy that I was actively cultivating with the community around me.

The intimacy of Eduardo's death was felt by most in the community and fed into a weeks-long uproar on social media. A group of Afro-Brazilian activists from the Complexo, known as the Colectivo Papo Reto (Straight Talk Collective), organized thousands of street protestors to march for an end to 


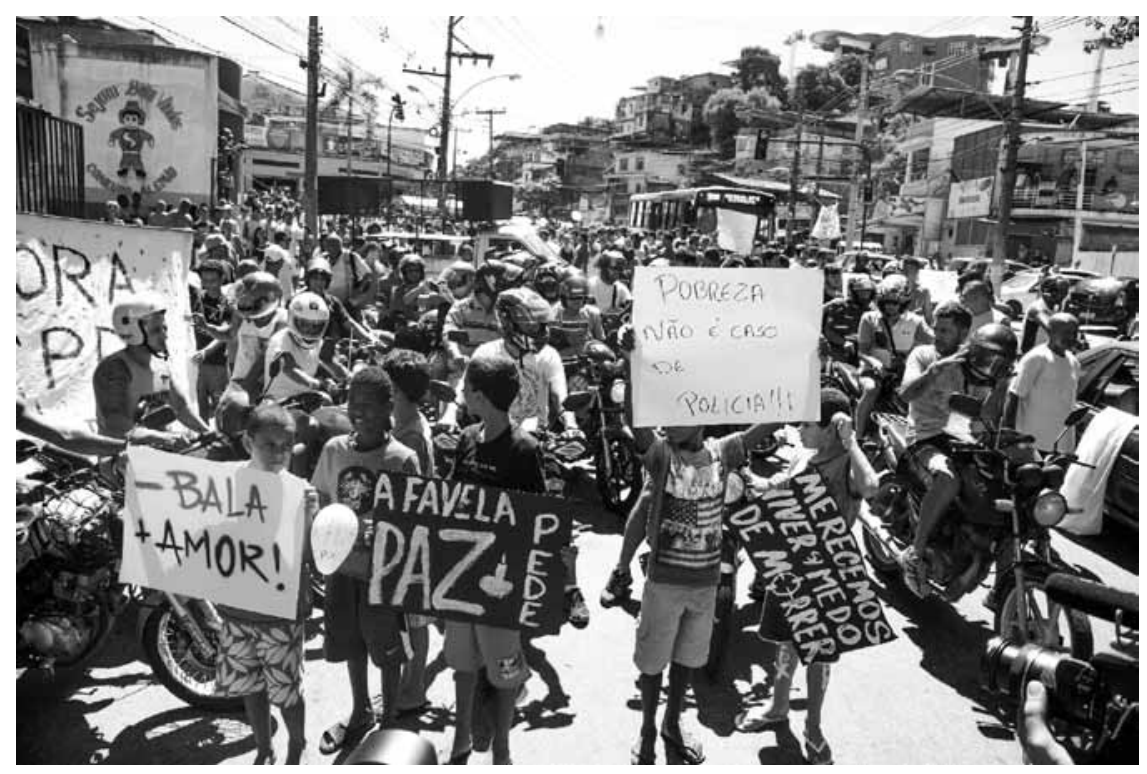

FigurE 1: Protest for Eduardo, 2015. Photograph $\odot$ Jason Bartholomew Scott

the police force that killed Eduardo. After years of carrying out participant observation with these activists, I recognized the march for Eduardo as one of their crowning achievements.

However, these achievements were short-lived. Within a few months, the police officer who had shot Eduardo was absolved of guilt by an internal review, and the intensity of police interventions into the Complexo escalated. From this point forward, the conversations I had with both police and activists were weighed down with fatigue and a sense of failure. Then in September 2019, a year in which Rio's police committed 1,814 homicides (Andreoni and Londoño 2020), an eight-year-old from the Complexo named Agatha Félix was killed as she rode home in a van seated next to her mother. A police officer riding alongside on a motorcycle looked through the van's window and mistook a smartphone for a gun, firing at the back of Agatha's head without identifying a target. Agatha's death, much like that of Eduardo four years earlier, sparked street protests and elevated the profile and cause of the Complexo's activists. Repeating a cycle I witnessed years earlier, police operations once again intensified, and activists' complaints against police violence were mostly ignored by policy makers.

Unlike years earlier, I was in the US when Agatha died and could only follow the events via social media. My response to Agatha's death felt lessened, more delayed, and emotionally cooler in comparison to the terrifying experience that I had shared with the Complexo after Eduardo's death. I instinctively tried 
to find a broken line of communication or a missed emotional cue. I quickly recognized that my initial interpretation of failure, one that focused attention on technological miscommunications, was a highly subjective projection of my own limits as a researcher.

How can ethnographers create a sense of continuity out of digital rupture? While I did not feel the same combination of emotional and physical terror for Agatha's death as I had for Eduardo's, digital observation is not emotionless. My desire to understand failure embraces the ethnographic practice of linking our ostensibly distorted digital world with something that seems more innate, embodied, and historical. For both activist and digital ethnographer, a sense of failure provides a means to empathize, to analyze shared goals, and to create new paths forward.

\section{Identifying Abolitionist Failure on Social Media}

While there is no 'right way' for activists to address the challenges they face, the way in which modern police abolitionists address these challenges determines their effects on a broader society (Freeman 1972). Abolitionists are opposed to the piecemeal reform of institutions and, instead, seek policies that will end, defund, and deinstitutionalize police forces. At a grassroots level, abolitionists seek to fire violent officers, support the families of victims, change laws, and organize street protests. Arguably, the principal challenge of modern abolitionists is to communicate a goal that is neither utopic nor dystopic, but rather an achievable public policy.

The use of social media has made abolitionists and their practices more visible. However, when new episodes of police abuse draw the public's attention on social media, provoking a sense of violent repetition and inescapability (Scott 2019a), the mere persistence of the carceral state instills a sense of failure. Rather than blaming shortcomings on individuals or the logical underpinnings of abolitionism or digital divides, many social media activists see the moral arc of history as long and failure as finite.

Twenty-first-century activists overcome their failures by connecting with a lineage of anti-racist humanist vocabularies and personalities that dates back to the nineteenth-century fight against slavery (Gross and Thomas 2017; Roberts 2019). The Internet allows activists to filter more historical and global logics through local idiosyncrasies (Bonilla and Rosa 2015; Juris 2016; Scott 2019b). An example of these memetic potentials is the recent globalization of the Black Lives Matter movement, often translated by Brazilian activists as "Vidas Negras Importam" and "Vidas na Favela Importam" (Favela Lives Matter). Memetic potentials also emerge as these phrasings are translated into different policy orientations (Scott 2020). While US abolitionists have called for 
“defunding the police," Brazil's social media activists have made similar calls for a ban on policing operations in the favela.

Social media allows activists in the US and Brazil to establish an ethical alignment but also creates space for highly situated public policy goals and expressions of failure. Considering the need for contextualization, the digital lexicon of abolition and failure is difficult to transliterate. Local definitions of failure are tied to an ethical reality of right and wrong (Sloane-White 2008), and public policies are often deemed failures simply by opposing a community's common values (Cernea 1997). Rio’s social media activists, for example, have yet to adopt the term abolicionismo (abolitionism) as a means to define their goal of dismantling a militaristic police force. Rather, while activists use the term fracaso (failure) to describe policing interventions, they more commonly invoke forms of deception (maquigem or make-up). Failure is symbolized in physical remnants, for example, defunct infrastructure and gravestones that suggest abandonment (abandona), and digital traces, such as social media posts from critical community members. Identifying expressions of failure as they evolve over time, particularly in the information age, requires a flexible set of definitions and a situated knowledge of how activist critiques are made visible or invisible on digital platforms.

\section{A Digital Ethnography of Failure in the Favela}

Relying on digital ethnography to examine the failure of activist movements can produce its own limitations and failures. Since 2008, I have documented a broader movement arguing for digital inclusion in the favela. I rely on both inperson and online participant observation to engage with social media activists, paying close attention to vocabularies concerning street-level violence that are mobilized on platforms such as Facebook and WhatsApp. This approach has taught me that digital traces, for example, 'likes', comments, and the sharing of content, are rarely precise indicators of a more embodied sentiment. When possible, more traditional ethnographic methods can inform digital engagements by developing historical depth and contextualizing a plurality of voices. Social media makes visible the more spectacular aspects of the favela's abolitionist movement, including the organization of street protests, outreach to journalists and scholars, and the proximity of leaders to policy makers. I find that more banal moments of abolitionism, such as organizing neighbors with limited political interest and jockeying for prestige, are less visible on social media.

As a form of pseudo-archival research, social media ethnography can provide unique insight into the contemporary history of an activist movement. The Complexo's modern abolitionist movement can be traced to the community's 2010 pacificação (pacification), when community members live-tweeted 
policing operations and gained tens of thousands of followers on social media within days. The Complexo's new police force, the UPP (Pacification Police Unit), promised to address social needs as well as security issues. However, activists linked the deaths of both Agatha and Eduardo to the proximity policing implemented by an increasingly renegade UPP. Within a year of pacification, "Fora UPP" (Get out UPP) became a common \#hashtag online, and dozens of activists from the Complexo now had thousands of followers on social media.

Digital ethnography reveals a more public organizational structure of a movement and how activists prioritize collective narratives. Following the social relationships of similar abolitionist movements, I engaged a core group of charismatic leaders and directly affected individuals (i.e., the formally incarcerated or mothers of victims) and a dedicated yet peripheral group of self-declared allies. Media visibility, money, and political access are valuable commodities within a movement. As these commodities 'change hands', activists experience a sense of conflict but also a desire for internal flexibility. Less prominent activists from the favela often complained about more prominent activists who traveled abroad for international conferences or corporate events while violence raged in their community. Prominent activists are sometimes deemed manipulado (manipulated) and accused of selfish political maneuverings or outright theft of donated goods. I hear these critiques frequently during street-level conversations, but it is nearly impossible to find negativity in a more public digital space. Conflict is often resolved through private conversations, and the public register of a critique is quickly deleted once bridges are mended between activists. Internal critiques and political maneuverings within a movement, however banal, are often omitted from the narratives that activists construct about their movements, and social media research has little recourse to account for the deletion and self-censorship of internal critiques.

Activists shape narratives about their movement by aligning themselves with authoritative actors in corporate journalism, political parties, and government agencies. However, even in the most transcendent movements, there can be deep-rooted forms of anti-blackness and anti-abolition that seep in through interventions made by parties outside of the movement (Wilderson 2003). For example, social media posts from favela activists are often used on Brazil's nightly news programs, and as a result many activists have become professional journalists. Large multinational corporations such as Microsoft, Unilever, Coca-Cola, and Petrobras also collaborate with favela-based activists. Corporate branding (Scott 2020) and a desire to reproduce middle-class consumerism in the favela (Scott 2019b) are two of the more visible ways that I found outside actors attempting to co-opt the Complexo's abolitionist movement. Paulo Freire (1970) refers to similar alignments as 'false generosity' where outside interventions often promise to address social problems but also maintain oppressive ways of knowing the world. This cloudiness between activists and powerful 


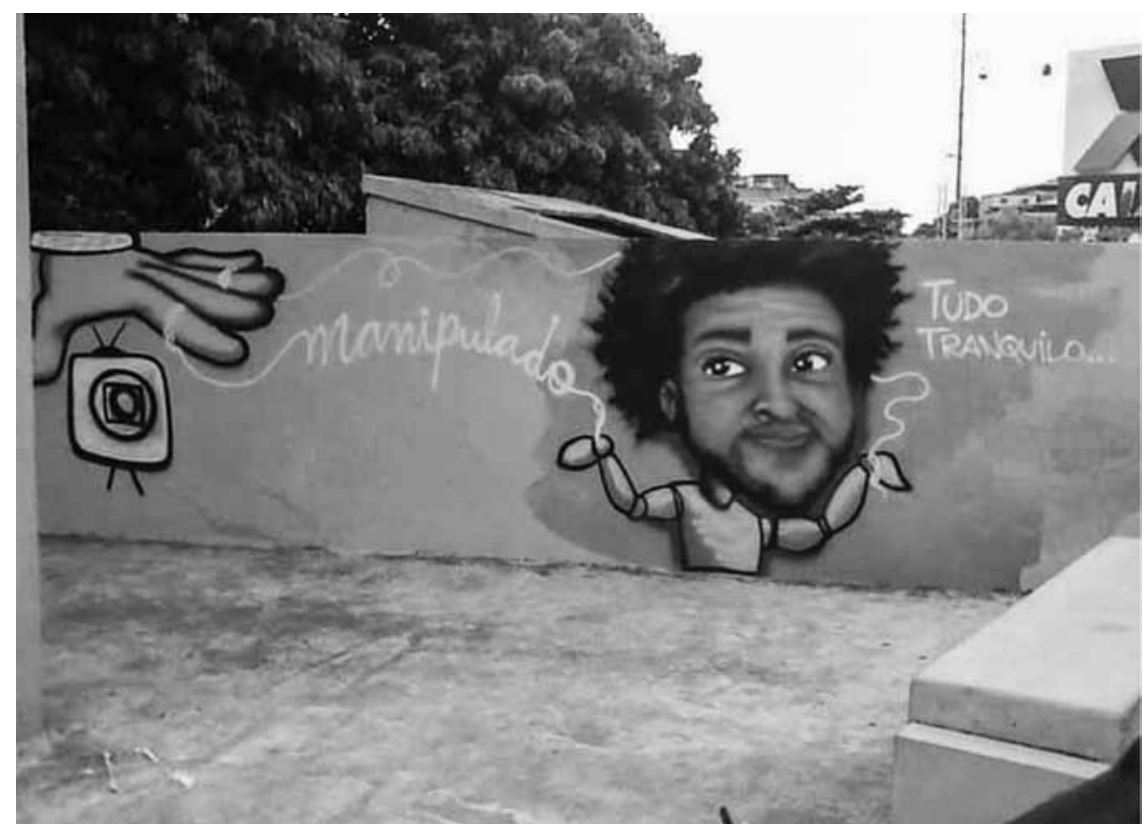

FIGURE 2: Caricature of a local activist, accusing him of being “manipulated” by Brazil’s largest media corporation. ${ }^{\odot}$ Jason Bartholomew Scott

outsiders can be intensified by social media. Once activists collaborate with an outside institution, their social media profile can be consumed with corporatebranded projects, making it difficult for allies and researchers to separate an activist from the brand.

Acts of overt censorship, from police and other violent actors, also present a challenge to favela activists (Martins 2019) and can cloud activist online messaging. Favela activists have experienced criminal investigations, have met with direct violence, and have covertly mobilized 'fake news'. Counter-abolitionists claim that the favela's human rights activists are making an anarchistic apologia ao crime (apology for crime); they often shift the definition of victimhood toward themselves and suggest that abolitionism threatens the welfare of police officers and everyday citizens. In the US, slogans like "Blue Lives Matter" and "All Lives Matter" rely on a similar counter-narrative that diminishes experiences of exclusion and reasserts dominance over marginalized communities (Solomon et al. 2021). These counter-narratives suggest that social media has the same potential to be suppressed by the state as previous methods of social organization. Oppressors, much like liberators, are always poised to innovate. The particular digital blind spots that I encountered in the Complexo reflected a small step toward authoritarian misinformation in the favela and the desire of powerful actors to disrupt the relationship between abolitionists and their allies. 


\section{Conclusion}

A sense of failure is not the end of the road for activism or digital ethnography, but rather a reason to create new strategies (Musallam 2020). My own fraught relationship with online abolitionists follows a broader anthropological search for social continuity. In this example, an initial sense of ethnographic shortcoming, the feeling of a dissolution of a more physically defined field, was socially productive. I shared a sense of failure with my interlocutors, and in doing so I was made aware of strategies to adapt to a constantly innovating information society where social relationships and identities are constantly broken down and remade.

Orisanmi Burton (2015) describes a similar "explanatory crisis" for digital ethnographers who find themselves documenting lives of communities who can now speak for themselves. Much like abolitionist movements that are denied success, digital ethnographers must re-inform their work and develop new modes of communicating rather than relying on previous conceptualizations of in situ witnessing. Beyond looking for absences in digital research and gaps in the distorted nature of online platforms, or framing the shortcomings of abolitionism and social media analysis as a dead end, ethnographers can refocus on the generative aspects of failure. I sought to generate a new sense of field and community by aligning my sense of digital failure with the abolitionists' sense of disappointment.

My favela-based interlocutors suggest that-in activism and in ethnography - the failure of one set of strategies is not always an indication of defeat. As the result of the COVID-19 pandemic, police operations in 2020 were dramatically reduced in Rio's favelas, leading to an equally dramatic 72 percent reduction in homicides (Mena 2020). Finding an unexpected victory, the Complexo's social media activists organized to fight another case of government neglect. Repeating the earlier model of a mobile app that tracked police violence in the favela, activists developed a new tool to combat pandemic-related 'fake news'. The app included not only warnings about debunked treatments for the illness, but also case statistics that exposed government underreporting. The unresolved nature of Eduardo's and Agatha's deaths, the failure to find justice for two children murdered by agents of the state, helped to build the social media framework for future activism. If social media activists can recover from setbacks to lead their communities through the tumult of government abandonment and entrenched structural inequalities, surely ethnographers can find ways to emerge reanimated from our crises of digital representation. 


\section{Acknowledgments}

I would like to thank Geoffrey Hughes and Anna-Maria Walter for their support in bringing this project to publication. I also must acknowledge the human rights activists of the Complexo do Alemão who invited me into their homes and shared with me their hopes for a better world.

Jason Bartholomew Scott's long-term scholarship examines the parallels between abolitionist movements in Brazilian favelas and the Rust Belt in the midwestern United States. His research interests include community policing, digital inclusion, and social media activism. Currently, he is developing an ethnographic project concerning UX or user design in online prison classrooms. He teaches Anthropology at the University of Colorado and for a university program within Wisconsin prisons. He also lectures on Comparative Global Politics and American Politics for Carroll University. E-mail: jbscott@colorado.edu

\section{References}

Andreoni, Manuela, and Ernesto Londoño. 2020. “'Licença para matar”: Por trás do ano recorde de homicídios cometidos pela polícia no Rio" ["License to kill": Behind a record year of homicides committed by police in Rio]. New York Times, 18 May. https://www.nytimes.com/pt/2020/05/18/world/americas/rioabuso-policial.html.

Bonilla, Yarimar, and Jonathan Rosa. 2015. "\#Ferguson: Digital Protest, Hashtag Ethnography, and the Racial Politics of Social Media in the United States." American Ethnologist 42 (1): 4-17.

Burton, Orisanmi. 2015. "Black Lives Matter: A Critique of Anthropology.” Hot Spots, Fieldsights, 29 June. https://culanth.org/fieldsights/ black-lives-matter-a-critique-of-anthropology/.

Cernea, Michael. 1997. "The Risks and Reconstruction Model for Resettling Displaced Populations." World Development 25 (10): 1569-1587.

Freeman, Jo. 1972. "The Tyranny of Structurelessness." Berkeley Journal of Sociology 17: 151-164.

Freire, Paulo. 1970. Pedagogy of the Oppressed. Trans. Myra Bergman Ramos. New York: Continuum.

Gross, Ariela J., and Chantal Thomas. 2017. "The New Abolitionism, International Law, and the Memory of Slavery." Law and History Review 35 (1): 99-118.

Juris, Jeffrey S. 2016. "Reflections on \#Occupy Everywhere: Social Media, Public Space, and Emerging Logics of Aggregation." In Youth, Space and Time: Agoras and Chronotopes in the Global City, ed. Carles Feixa, Carmen Leccardi, and Pam Nilan, 385-414. Leyden: Brill. 
Martins, Gizelle. 2019. "Militarizaçã e Censura: A Luta por liberdade de expressão na Favela da Maré” [Militarization and censorship: The struggle for freedom of expression in the Maré favela]. Rio de Janeiro: Núcleo Piratininga de Comunicação.

Mena, Fernanda. 2020. "Proibição de operações policiais em favelas do Rio reduziu mortes em 72,5 percent" [Prohibition of police operations in the favelas of Rio reduces deaths by 72.5 percent]. Folha de São Paulo, 3 August. https://br.noticias.yahoo.com/proibi\%C3\% A7\%C3\% A3oopera \% C3 \% A7\% C3 \% B5es-policiais-em-favelas-162200467.html.

Musallam, Fuad. 2020. “'Failure in the Air”: Activist Narratives, In-Group StoryTelling, and Keeping Political Possibility Alive in Lebanon.” Journal of the Royal Anthropological Institute 26 (1): 30-47.

Roberts, Dorothy E. 2019. “Abolition Constitutionalism.” Harvard Law Review 133 (1). https://harvardlawreview.org/2019/11/abolition-constitutionalism/.

Scott, Jason Bartholomew. 2019a. "Death on Repeat: Violence, Viral Images and Questioning the Rule of Law in Brazilian Favelas.” Journal of Legal Anthropology 3 (1): 21-40.

Scott, Jason Bartholomew. 2019b. "Utopia Digital: Non-governmental Organizations and the Making of Consumers in Brazil's 'New Middle Class' Shantytowns.” Journal of Consumer Culture. https://doi.org/10.1177/1469540519890000.

Scott, Jason Bartholomew. 2020. “Microsoft's Drug Dealer: Digital Disruption and a Corporate Conversion of Informal Improvisation.” Tapuya: Latin American Science, Technology and Society 3 (1): 512-527.

Sloane-White, Patricia. 2008. "The Ethnography of Failure: Middle-Class Malays Producing Capitalism in an 'Asian Miracle' Economy.” Journal of Southeast Asian Studies 39 (3): 455-482.

Solomon, Johanna, David Kaplan, and Landon E. Hancock. 2021. "Expressions of American White Ethnonationalism in Support for 'Blue Lives Matter.” Geopolitics 26 (3): 945-966.

Wilderson, Frank B., III. 2003. "The Prison Slave as Hegemony's (Silent) Scandal.” Social Justice 30 (2): 18-27. 